\title{
The network commons and the city as project and Utopia
}

\author{
Armin Medosch \\ Deceased, formerly of: Faculty of Media and Communications, \\ Singidunum University, Belgrade, Serbia
}

\begin{abstract}
The network commons is a techno-utopian project which proposes an alternative, social use of technology. Together with other initiatives, it could form a nucleus of a socially transformative project - a potentially worldchanging force based on commoning practices arising from within global society. In order to avoid the mistake of internet utopianism of the 1990s, I propose to place the network commons and the larger commons movement in the context of a discourse on the city as utopia and project. In order to develop a new project and utopia we need to understand and respond to the new capitalist logic of network society and how it has reshaped the city.
\end{abstract}

Keywords: network commons; commoning; urbanism; Fordism; network society.

Reference to this paper should be made as follows: Medosch, A. (2018) 'The network commons and the city as project and Utopia', Int. J. Electronic Governance, Vol. 10, No. 2, pp.120-137.

Biographical notes: Armin Medosch, $\mathrm{PhD}$, was an artist, curator and author working in art, media theory and network culture. He was the initiator of the Technopolitics working group in Vienna and initiator and maintainer of the cooperative web-space thenextlayer.org. His book under the title "New Tendencies - Art at the Threshold of the Information Revolution" was published by MIT Press in June 2016.

This paper documents the keynote speech that Armin Medosch gave during the 3rd Hybrid City Conference in Athens in September 2015 (www. media.uoa.gr/hybridcity).

\section{Introduction}

The network commons is one of a number of cooperative models emerging from within advanced informational capitalism. It relies on forms of commons-based peer production, which were first practised in the digital domain. Now, in the era of permanent crisis, new alliances become visible, where commons-type ecologies are also practiced in domains such as alternative agriculture, time-sharing, solidarity economics, and alternative energies. I propose the hypothesis that as long as all those initiatives remain separate, they will either be absorbed or made impossible by capitalism. There will be some change in limited areas, but the overall political economy and system that creates inequality and poverty will not change. A new narrative is necessary, a coherent and collective vision that brings those different currents and tendencies together. I am not in 
the position to offer such a narrative single-handedly. This is something that has to arise from global society through many narratives, efforts, models. Such a new narrative should also not exist in an abstract, empty historical space. I propose to place the network commons and the larger commons movement in the context of a discourse on the city as utopia and project. That phrase refers to Manfredo Tafuri's book Progetto e Utopia (Tafuri, 1973) in which 'the plan' occupies a central position. Tafuri brings together the notion of a planned Keynesian economy with that of the blueprint of a building or urban design (Tafuri, 1976). 40 years after Tafuri's work was first published, there is no more plan and the capitalist logic has changed profoundly. In order to develop a new utopia and project, we need to understand that new capitalist logic and how it has reshaped the city. But first I will discuss the concepts of 'the project' and utopia in principle.

\section{Utopia and project}

The notion of a 'project' is shared among Marx and Marxist authors such as Ernst Bloch, Herbert Marcuse or Henri Lefebvre. Utopia is generally seen as a non-place, as an ideal city-state that exists only in a fictitious world, such as Tommaso Campanella's City of the Sun (Campanella, 2009) or Francis Bacon's New Atlantis (Bacon, 2014). This type of utopia could actually prevent change because it projects an ideal into a never attainable otherworld, an Ersatz-heaven, a substitute for a real change in this world. Therefore, the notion of the project comes in, as a concrete utopia. The project oscillates between something that is distinct from utopia insofar as it projects a future that is actually attainable; and something that is almost as utopian as utopia insofar as it dares to formulate a collective future that is substantially different from and better than the current social form.

Seen from this specific angle, the project until quite recently consisted of the essence of the larger historical movement of socialist, modernist emancipation. Such a notion of the project was a powerful meta-narrative that worked across media, materialities and texts. It was philosophically underpinned by a Marxist-Hegelian view of history. Young Karl Marx, influenced by Hegel, thought that history is the self-creation of man. "The entire movement of history is", Marx wrote, "its actual act of genesis (the birth act of its empirical existence), [but] also for its thinking consciousness the comprehended and known process of its coming-to-be" (Marx, 1972, p.84) emphasis in the original). As Herbert Marcuse wrote, "the subject must make the world its own doing if it is to recognize itself as the only reality. The process of knowledge becomes the process of history" (Marcuse, 1971, p.95). History is about historical self-creation as a political act, a self-instituting process. A historical subject, the bourgeoisie, the working class, creates itself, it turns itself from an object into a subject. It does so consciously, out of a given historical situation with its conditionalities. The human subject, as a collective speciesbeing, transcends and transforms the conditions of its being.

My suggestion is thus not to create a trivial project - in the way that we use this term to describe things that we want to do - but a project as a collective undertaking. This endeavour will need to take a fresh look again at utopia. If we take Ernst Bloch's notion of utopia, it is not just a non-place but something that is highly active in the here and now (Bloch, 1962). Bloch's utopia is also more than the rational projection of a better future probably better associated with either vulgar Marxism or a 'red philistinism' - which is a surplus of thinking that he locates in art, literature, philosophy (Bloch, 1988, p.40). 
Bloch's ideas were based on a complex, non-linear understanding of time, influenced by Walter Benjamin (see for example (Bloch, 1988, p.217). For Bloch, utopia was not just a projection of a future but something present in every lived moment - similar to Benjamin's 'messianic time' - as a potential for the actual transformation of the world. The material for such a supercharged moment - or now-time - was to be acquired from cultural heritage, not only in art but also children songs, myths, and fairy tales (Bloch, 1988, pp.215-217). History, in such a viewpoint, is always a dialectic between the actual constraints of reality and the open potential of now-time.

The city as utopia and project thus starts from the actually existing historical situation. In this situation, critique has become ineffective because the elites have abandoned the emancipatory narrative of modernity. As we shall see in one of the sub-chapters that follow, in informational capitalism critique has become the engine of product innovation in postmodern production. Rather than critique, we need to rewire the strings that connect network society to create new force fields that drive change to a different direction. The project is the sum of all those ideas, a collective utopianism, but one that has vibrant connections with reality.

\section{The commons and commoning}

My proposal takes as its starting point recent attempts at creating a network commons. Groups of socially engaged computer technicians and network enthusiasts are working on creating alternative networks. Those networks are based on internet technology, and are not owned by corporations but by the people who use them. The physical network structure is held in common. The protocols that actually manage the data flow are also held in common. The network commons is part of a vibrant heterogeneous movement to create a digital commons. Since the success of Linux in the early 1990s, free and open source software has become hugely successful. Many important types of computer software are created by people engaged in voluntary free cooperation, also known as commons-based peer production (Benkler, 2006). This method has proven to be hugely successful and people have tried to apply it to other areas rather than just software, such as cultural production. The Creative Commons licenses (Berry and Moss, 2009) have been created to allow sharing of intellectual and cultural products. Wikipedia has become a model for shared knowledge. Many initiatives now exist to create open and shared resources in the digital domain, from open data, to open access journals and open sensor networks. The digital commons (da Rimini, 2007) - a wide range of different initiatives to create and maintain open and publicly usable information infrastructures - is part of a larger societal shift.

The notion of the digital commons has emerged from cooperative hacker culture within computing. Meanwhile, this notion starts to develop links with another discourse on the commons which comes from what was once called the developing world. In poor nations, mainly in the global south, ecologies based on the sharing of common resources are still pretty much in place. The process described by Marx whereby subsistence farmers are turned into worker-consumers (Marx, 1976), is happening every day. The commons of all types and shapes and economies and ecologies of solidarity have become an alternative vision of a post-capitalist economy, promoted by activists such as Michel Bauwens, Silke Helfrich, and David Bollier. Bauwens thinks that peer-topeer networks hold the power to an alternative economic model. In books such as 
Die Welt der Commons (Helfrich et al., 2015) Helfrich and Bollier have collected many examples of successful commons. They are convinced that the commons can become the centrepiece of a new post-capitalist political economy. In order to avoid the reification of the notion of the commons, they have turned it into a verb, commoning. According to Bollier and Helfrich, the commons is not a thing but a mentality, an attitude. They relate this attitude to the notion of conviviality, citing Ivan Illich (Illich, 1973) as source. Conviviality is also an important notion in the writings of Karl Marx, as Nick Dyer-Witheford (Dyer-Witheford, 1999) has pointed out. Unlike Marxists though, commonists talk the language of 'transition'. In their view, a new society, in whose political economy the commons plays a central role, does not need to be created through revolution but can arrive slowly, through a social evolution, which may eventually result in a 'phase transition' using a metaphor from physics. It is quite easy to dismiss this as romantic idealism. Yet there is nothing wrong with this if it is paired with hard-nosed realism. Let us suspend judgment and keep the notion of commons and commoning in storage as something that may sound slightly utopian, yet in certain cases has found realisation in this world.

My suggestion is to bring together the notion of the network commons with the city as utopia and project. The thinking behind that is that the city allows to better anchor that project in reality. Rather than arguing in front of an abstract historical space, the city is the place where this concrete utopia can emerge. Therefore, we need to take a look at recent paradigmatic transformations of the city.

\section{The Fordist city}

The Fordist city had its social origins in the project of modernity. It superseded the great bourgeois city which had superseded the medieval city, as in the case of Paris, where old quarters were destroyed by Baron Haussmann to create a large-scale urban axis, the boulevards. Many problems and social ills of the great bourgeois city of the 19th century were addressed by the hygienic movement, the Garden city movement and by socialist workers movements whose projects impacted on the bourgeois city to create the Fordist city. Generating the plan for the Fordist city, however, became only possible after the bourgeois society destroyed itself in the Great War of 1914 to 1918 and after the artistic avant-gardes cleared the underbrush of what Herbert Marcuse called affirmative culture (Marcuse, 1968). Constructivism and Dadaism broke the path for the society based on 'the plan' and the functionalist architectural utopia, argues Manfredo Tafuri. According to Tafuri, the city is "objectively structured like a machine for the extraction of surplus value". [...] The city "in its own conditioning mechanisms reproduces the reality of the ways of industrial production" (Tafuri, 1976, p.81). In other words, the structure of the city is representative of the most pointed expressions of a specific mode of production and the social relations on which it depends. This means that on the layer of work there are specific ways of working which articulate the essence of the respective current techno-economic and political paradigm. The artistic avant-gardes focus on this layer of work by making art that encapsulates in the object a specific relation between manual and intellectual labour. In other words, there is a link, via the layer of work, between the artistic avant-gardes and the social avant-gardes.

Although Dadaism and Constructivism are viewed as bipolar opposites in conventional art histories, contact between representatives of those movements was 
strengthened in the early 1920s. In Tafuri's reading, Dada had to get rid of the entire cultural heritage of bourgeois society in order to set free the internal dynamics of that society (Tafuri, 1976, p.56). Dada's aesthetic shock tactics were a requirement to wake up people, to open them for "that reality, in that field of indeterminant, fluid, and ambiguous forces" (Tafuri, 1976, p.56) whereby 'that field' was the space of the electrified metropolis governed by the circulation of money and commodities. The incessant stream of money, signs, people and commodities created, according to Georg Simmel, a specific condition for the mental life of the urban dweller, characterised by a constant tension between a heightened, feverish attention to the present and a retreat into a shell by the person who presents a blasé attitude to the outside world (Simmel, 2000). Dada's aesthetic clearing of the underbrush reduced language to the individual typographic character as a liberated sign. This made Dada a direct precursor of information theory and its application to art. "The only utopia the art of the avant-garde was able to proffer was the technological utopia", argues Tafuri (1976, p.152). Whereas the constructive avant-gardes "became a method of formal control of the technological universe, Dada wanted to enunciate apocalyptically its immanent absurdity" (Tafuri, 1976, p.92). While constructivism strove to find ways of creatively controlling the power of technology, Dada released that power as a kind of negative, Nietzschean 'gay science'. Both projects, the politicised Berlin Dada of 1920, and the Constructivism of Lissitzky, van Doesburg and Moholy Nagy converged on some form of socialism understood as accelerated accumulation (Tafuri, 1976, p.69). Yet by 1922 the most progressive members of Dada and Constructivism had to concede that they were "standing between a society that does not need us and one that does not yet exist" (van Doesburg et al., 1922). The artistic avant-gardes had staked out the framework for the Fordist city but were unable to set it into action. That was left to architecture, business and politics.

The Fordist city was a combination of industrial mass production of consumer goods based on techniques first assembled into one machine by Henry Ford, together with policies aiming at creating an equilibrium between production and consumption commonly attributed to John Maynard Keynes. Yet the problem had already posed itself immediately after Henry Ford had switched on the first assembly line at Highland Park in 1913. The new production mode was not only dependent on a new type of worker, it also needed consumers. Ford's solution, famously, had been to double the average daily wage for workers (Batchelor, 1994, p.23). Despite that, the impossible demand of the Fordist assembly line on workers created an extremely high turn-over rate of $300 \%$ in the early years (Batchelor, 1994, p.23). The 'new man' who would be capable to withstand the shock of working under the dictate of the assembly line had yet to be created. Tafuri, influenced by Italian autonomous Marxism, recognised that long before Keynes, at around 1920 in Germany, far-sighted industrialists such as Walter Rathenau had acknowledged the potential of a controlled, planned society based on an equilibrium between production and consumption as the only way forward. The political emancipation of the working class was expected by social democrats to be brought about by a functionalist and technological system. Tafuri conflates the meaning of plan as an architectural plan with that of a planned, Keynesian economy. Yet after the failure of socialist revolutions in Germany, and after the murder of Rathenau in 1922, the German industrial leaders saw no more need for a compromise with the organised labour movement, paving the way, in the long run, for the great depression and fascism. Fordism proper came only into place in the USA with the New Deal and in Europe after 1945. 
The Fordist city as such was never built, except as model cities, such as Ernst May's New Frankfurt and the public housing buildings of Red Vienna, such as Karl Marx Court. According to Tafuri, the functionalist utopianism of Le Corbusier and CIAM paved the way for the ideology of the new town after 1945 and what Reyner Banham called a New Machine Age (Banham, 1962). While planned according to some of the ideals of the Garden City movement, the new spatial arrangements of the Fordist City impacted negatively on 'networks of kinship', as a famous study from the 1950s was called (Young and Willmott, 1986). Modernism as a program was still running its course in the second half of the 20th century, but it had lost traction among the avant-gardes. The artistic avant-gardes, between 1916 and 1922, and the architectural avant-gardes, from the early 1920 s to the mid-1930s had contributed a utopian spirit to the technological society of the plan. Once the plan was actually carried out neither artists nor architects were needed anymore. The 'plan' - understood as the embodied ideology of societies of mass production and mass consumption - was not executed by architects and visionaries but by civil engineers and accountants.

The Fordist city was the city of the atomised individual and the family as the nucleus of society. The atomised structure was overlaid by force fields of mass media communications through radio, television and illustrated mass media magazines and the yellow press whose task was to inform the people about the new modes of consumption. Consumerism had to be learned and the mediated city was the place where that was to take place. The Fordist city was characterised by the separation between producers and consumers, order givers and order receivers, senders and receivers. It created a society based on top-down cybernetic control mechanisms.

\section{The revolutions of everyday life}

Mass media were created as a direct consequence of the requirements of mass production. The 'new man', both as producer and as a consumer, had to be created, there was nothing natural about her or him. In the process, a long-term tendency of secularisation took place. What Walter Benjamin discerned as the loss of the aura in the reproducible artwork was according to Henri Lefebvre only following the "law of the transformation of the irrational" (Lefebvre, 2014, p.137). Writing in the 1940s and 1950s, as consumer society was in its early stages, Lefebvre argued that all that had been deep, cosmic, mysterious, magic, ritual in the relationship between man and the world gradually had become demoted and had "fallen down to the level of the weird and bizarre" (Lefebvre, 2014, p.137). Yet at the same time as this demotion took place, an internal transformation happened of that which was deep, cosmic, and affective: "[it] sooner or later gradually enters the domain of play, or art, or just simply becomes amusing or ironic verbalization" (Lefebvre, 2014, p.137). Everyday life, experienced in stark contrast to sensations of the bizarre and extraordinary provided by the media spectacle, becomes dissipated with a feeling of disappointment and dissatisfaction. If a political utopianism was to be recovered, Lefebvre suggested, this could happen only through "a rehabilitation of everyday life" (Lefebvre, 2014, p.147).

The marvellous and mystery had been demoted in the secularised Fordist City and relegated to a niche existence. This does not mean that Lefebvre suggested a 'going back' to a more organic, communitarian city life. What he suggested was that only through attention to the apparently banal aspects of everyday life could utopian ideas be 
recuperated (Lefebvre, 2014). A political critique that was oriented towards praxis, towards a realisation of political philosophy in life, could not only focus any longer on those domains traditionally associated with politics, such as political parties, and the state. It would also have to proceed from the critique of everyday life. Lefebvre's rebellious disciples, the Situationists actually claimed that political revolution had to be raised from the ground up, through the decentralised passions of the many revolutions of everyday life (Debord, 2004; Vaneigem, 1983).

The Fordist city had only become reality in model projects which did not affect the remaining city surrounding it. In that what remained, the contradictions of capitalism continued unabated. Fordism reproduced the contradictions of capital on a higher and accelerated technological level. Those contradictions came crashing down during the global revolts of 1968. The ideas of Lefebvre and the Situationists were put to the test by the revolutions of 1968, from the Parisian May to the many revolutions and revolts that broke out simultaneously nearly all over the world. It was a revolution against the social and political forms of Fordism understood as top-down cybernetic control loops.

\section{The networked or projective city}

As Fordism has been replaced by the Network Society (Castells, 2010) the restructuring of the city resulted in the networked city, which can also be understood as the projective city (to be differentiated from the city as project). The projective city is a metaphorical term brought forward in The New Spirit of Capitalism by Luc Boltanski and Eve Chiappello (Boltanski and Chiapello, 2005). The projective city is based on a new flexible regime of accumulation, a term introduced by David Harvey (Harvey, 1989) and later elaborated by Brian Holmes (Holmes, 2004). Flexible accumulation is the result of a long transition that started at around 1968, then intensified between 1971 and 1973, and finally found expression in a new techno-economic and political paradigm, the network society, which was instituted in the early 1990s and is still in place today. The 'flexible' aspect in flexible accumulation is the result of "a direct confrontation with the rigidities of Fordism" (Harvey, 1989, p.147). While Fordism was based on lifelong jobs and a planned balancing out of production and consumption, after 1968 a number of processes conspired to bring about the flexible regime. Fordism, in the highly industrialised countries, most notably the USA, experienced a profound crisis of profitability starting in 1967 (Brenner, 2002). The business started, on one hand, to intensify the automation of labour, in particular, the automation of intellectual and creative labour; and secondly, business began to relocate production to low-wage countries (Froebel et al., 1980). Both measures were, in a first stage, not capable of stemming the crisis of Keynesian Fordism.

"The Crisis of the Planner State" (Negri, 1988) was lucidly perceived by Toni Negri in a conference paper written in 1971 just weeks after US President Richard Nixon had suspended the Dollar to gold convertibility which had stabilised the postwar financial system. Drawing on famous passages from Karl Marx's Grundrisse (Marx, 1993), Negri explained important yet still poorly understood consequences of the 'general intellect' reaching a certain level. According to Negri, the planned economies of Fordism had managed to only temporarily stabilise capitalism without resolving its contradictions. One of capitalism's central contradictions is that its inherent progressive tendency on the technological side is held back by conservative social relations. On the one hand, due to the laws of competition, capital has to constantly engage in innovation through the 
development of science and technology. Through capitalist innovations, new modes of production are created, which have the potential of completely changing social relations. Yet this potential for the social good is constantly thwarted by capitalism's other need to maintain current social relations of production.

The existing social relations, the current class structure of society, has to be maintained. Marx has expressed this most pointedly: The combined power of all this highly skilled human labour develops the general intellect which reaches a stage where it would "blow the foundations of industrial society sky-high" (Marx, 1993, p.706). According to Toni Negri, industrialised countries had reached that stage in the 1970s. Science and technology can be viewed as accumulated, dead labour. As capitalism mobilises this accumulated dead labour, there is a disproportion between dead and living labour. While workers as individuals have to enter the labour market, they are pitched against the accumulated mass of dead labour, contained in scientific knowledge, technologies, machines. At that moment, individual labour time ceases to be the foundation of value. Whence labour time no longer forms the basis of prices, there is no real mediation anymore between capital and labour. There is no contradiction between capital and labour, whereby contradiction is understood dialectically as an engine of antagonistic historical development.

The new type of working-class struggles in Italy of the 1970s movements, in which Negri was closely involved, was bearing witness to the categorical change of how capital and labour were from now on to oppose each other in the West. Workers began their Exodus from the factory regime. The new type of activists were not workers in the classical sense anymore but artists, students, squatters, long-term unemployed, anarchists. Following Mario Tronti's earlier analysis about the 'social factory', they turned the city as a whole into the new battle ground using strategies such as self- reduction (refusals to pay increases in rent and social services such as electricity).

What Negri was unable to spot at the time was another historical tendency which concurrently intensified. As the United States was locked into an ideological battle with the Soviet Union, it spent enormous sums of money to beat its rival for global hegemony. The surplus of Fordism was invested into a military Keynesianism (Mandel, 1978). The unintentional side-effect of that was the invention of the internet. The internet has created the conditions for capitalism to get superseded. I do not claim that the internet was invented with anti-capitalist ideas in mind, but that, as an unintended consequence of high spending on information and communication technologies, ideas arose for techniques and protocols that have an unmeasurable potential for the social good. Moreover, the way in which those technologies were created was based on a type of freedom that existed, at the time, only inside the closed worlds of Cold War computer science (Edwards, 1996). The high-tech bubble of military Keynesianism enabled a commons-based peer production as a new production method amongst those scientists and engineers inside the apparatus.

The computer revolution gathered pace in exactly that same year when Negri wrote about the crisis of the planner state. This was 1971, when the first microprocessor was produced by Intel (Perez, 2009). Later, as computers became cheaper and more widely available, together with the opening of the internet, everybody could engage in commons-based peer production. As Marx had predicted correctly in the fragment on machines and the general intellect, advanced capitalism, through the systematic use of science and technology - in this specific instance computer science and information technologies - had created the conditions to blow the foundations of this society sky-high 
(Marx, 1993, p.706) as far as the mode of production was concerned. Yet, on the other hand, this potential had to be curtailed, because of the need of the capitalist class to maintain social relations. The result was, as Negri foresaw, pure class antagonism, whereby the planner state was replaced by the crisis state, which eventually led to the Thatcher-Reaganite regime and the neoliberal state. While the planner state had been based on mediation, the neoliberal state became based on exclusion and suppression.

In the 1990s, the surplus created by advanced capitalist society allowed a growing number of people to participate in creative economies and in peer-based-commons production. After labour had started its voluntary Exodus from the factory, capital answered by relocating labour elsewhere. The antagonistic tendency, as Negri called it, between capitalism and labour in the 1970s, triggered a complex wave of innovations which were not only coming from the top, imposed by business leaders, but also from within society. The outcome was the flexible regime as Boltanski and Chiappelli (2005) saw it: in this flexible regime, the life-long job was replaced by a succession of projects in which networked individuals come together for a limited period. The individual is no longer a wage worker who does a job, but like an artist, a highly motivated creative worker who seeks the realisation of the self through those projects. The project creates a highly activated segment of a network with dense connections between protagonists which intensify into a critical mass of active links. The latter are able to create new forms, what Boltanski and Chiappello call "a temporary pocket of accumulation" (Boltanski and Chiapello, 2005, p.105).

Moreover, the authors claim that those pockets of accumulation actually realised the demands of the revolts of 68 , albeit in commodified form. The changes demanded by the 68 generation in those areas where the personal becomes political (Boltanski and Chiappello call it 'artistic critique') have been captivated by the new spirit of capitalism and streamlined into new products and services. This aspect of their critique is controversial. It appears as too much of a generalisation to suggest that everything that the 1968 generation threw at Fordism in terms of critique was simply used by the system and mobilised to create new commodities. But, arguably, something akin to what they described was actually happening. The core recognition is that capitalism is capable of mobilising terms and concepts that have developed outside it, autonomously, and use it to its advantage - which is another meaning of 'flexible accumulation'. Capitalism is a dynamic and creative force which has the capacity to appropriate concepts developed outside itself and turn them into new sources of profit.

By the early 1990s, the projective cities had become a reality. The changes initiated in the early 1970s brought about a new regime of accumulation in which financial markets, networked and digital, played an important role. Informational capitalism is based on a new international division of labour which concentrates the production of goods in low wage countries but keeps the intangible goods concentrated in the hands of multinational corporations. A key technique for the management of production is the so-called just-intime (JIT) production, also known as global logistics chains. JIT is the decentralised global workhorse, based on driverless forklift trucks in container terminals and superfreighters operated by small crews, everything held together by data networks. JIT is the capacity to orchestrate production over different continents and time zones while at the same time releasing direct control over the parts. The new globalised cybernetic corporation has subjected all those activities to outsourcing which only promise a low return on investment, but the corporation keeps central control over the production and management of intangibles which secure long-term survival and profits. This has led to 
new mystifications of informational capital. ${ }^{1}$ One of those mystifications is the vanishing of the working class. Informational capital uses wage differentials between countries to maximise profit. This means that those in the rich countries never see and meet the people who produce the products for them. This has weakened the workers movements in rich countries and has led to the impression that there is no such thing as the working class anymore. Since the 2000s Toni Negri has tried to talk up the multitudes as a compensation for the vanishing of the working class (Hardt and Negri, 2001). Yet there are few signs that the multitudes are really finding itself as a historical subject.

The abstraction and extraction of value had also had implications for the dominant ideology. The appearance of the waning importance of material production has furthered the flourishing of various theories of immateriality, of a weightless economy, of immaterial labour, of capitalism having become 'cognitive'. The belief in the superiority of immaterial over material things has also led to the belief that stock markets and hedge funds are disconnected from the real economy. Those ideas, whether coming from the left or the neoliberal right mystify social relations in the information society.

The sociologist Saskia Sassen has asked the question, where do those disembodied communications in electronic networks actually touch the ground. She found out that although at the time of her initial study, around 1990, the properties of disembodied information were hailed, there were actual places and spaces where those new forms of communication touched the ground, which she called The Global City (Sassen, 2001). Those were cities such as Hong Kong, New York or London, which had little to do with their hinterlands or the nations they belonged to, but were interlinked in high-speed communication networks which fostered new forms of financial speculation in derivatives. Today the system of global cities has expanded and consolidated. The global city needs to be thought together with the projective city and the new conditions for immaterial and cognitive labour. Returning to Tafuri's central idea, the city needs to be understood as a machine optimised for the accumulation of capital. In the transition from the Fordist to the networked city, the character of this machine has changed profoundly. It is no longer a mechanical machine, but a non-trivial machine of second-order cybernetics. Aspects of it could probably best be described by the notion of the machinic, the machine-like working of the subconscious which melts - falls into one - with the statistic pools of desire produced by individualised advertising machines (Guattari, 2011).

Sassen's important finding was that speculative financial capital is depending on actual places. The allegedly virtual market places of the global cities have to be based on support structures that need the actual cities as those places that foster exchange between speculative financial capital and the professional classes it relies on, such as lawyers, accountants, policy makers, think tanks. Besides those professionals directly engaged in supporting financial markets, there is also a second layer of professions that provides the quality of life that those creative classes (Florida, 2002) need, in order to function. The projective city creates the new tastes and textures, nouvelle cuisine, bars and nightlife scenes, museums of modern and contemporary art and types of cultural production that provide the conditions for a liberal, multi-ethnic, cosmopolitan life. In the late 1990s, musicians such as LTJ Bukem and Talvin Singh created intelligent drum-and-bass for cognitive capitalists; pioneering contemporary art gallerists swarmed out into the most downtrodden corners of the city, their activities conspiring to aid and abet gentrification. In the city of postmodern production, this term production takes on an entirely different meaning. Lefebvre's critique of everyday life is now realised in a negative dialectics. As the creative class produces the new textures of the digital 
aesthetics, gentrification reshapes inner cities according to its needs appropriating urban space for an aestheticised, pseudo-individual hipster consumerism. Real estate speculation in the global informational city creates huge disproportions between house prices and the incomes and needs of working people.

It is against this backdrop that my impossible proposition is made. Tafuri wrote 'project and utopia' when the plan was first called into question seriously, in the early 1970s. The elites had secretly stopped subscribing to it and unfurled plan B, a switch to the free market ideology. We have now had 40 years into the opposite direction. It is from this position that I suggest a re-engagement with terms such as project and utopia. After more than 40 years of neoliberalism, our language of hope has impoverished. There is no more plan, no more project that seeks to bring on board as many people as possible. The new logic is one of naked extraction of profit with a disregard for the majority of people. While the class of producers has become invisible to the people who consume the products they make, the class of property owners who extract rent from the projective city are also invisible. There is no negotiation, no mediation, just abstract total capital and abstract socialised labour confronting each other.

\section{The rise of the network commons}

At around the year 2000, more or less simultaneously in London, New York, Seattle and Athens a series of projects started to build wireless community networks. A little bit later, in 2003, a similar project started in Berlin and rural Catalonia. Those initiatives used a license-exempt part of the electromagnetic spectrum and Wifi, also known as wireless local area networks (WLAN), (Lemstra et al., 2010) to build community networks, which were owned and maintained by the people who used them. The impetus for those projects came from many directions but one shared motivation was the perception that through the New Economy of the 1990s and the privatisation of the internet the original idea behind the Net had become distorted. A basic property of the internet protocols that were developed since the late 1960s was that they allowed creativity at the edges. That means that everybody could connect to the internet who had the know-how and ability to do so; this was a network of networks that was not owned by one entity. Once online, communication was, on a technical level, symmetrical - it had the same speed in both directions - and non-discriminatory - data packets were not filtered according to criteria of what was transported. At the time, broadband internet was still difficult to get or expensive or both, and the sale of frequencies to mobile telephony providers had just begun, who followed entirely different business models from those of early internet providers. Apart from an interest in free flow of communications, the new brand of wireless community networks had many other different motivations.

Each of the projects adopted a slightly different technological approach. The Athens Wireless Metropolitan Network (AWMN) was started mainly by technology experts. Using the urban topology of Athens with its hills and cooperating with radio amateurs, AWMN activists were able to create a network that covered a vast area, the Attica peninsula and beyond. The social model was based on the liberal utopia of individual ownership. Each node was built and maintained by its users, all the nodes together formed - and continue to do so - a network commons. The particular idea of AWMN was that it did not offer internet access. Some nodes were connected to the internet but this was not publicised as a reason to join the network. The idea was that the network 
builders would together create a network which would be attractive to its users because of its services. Services offered included mirrors of free software repositories, file sharing, streaming services, games, voice over IP and much more.

Consume in London proposed a slightly different idea which was informed by experiences with Backspace. Backspace had been a net art creative hub in central London, with a fast synchronous network connection. Through WiFi, the net became a shared resource, both as an intranet and as a network that connected with the wider world. Backspace and other studios and workspaces connected to it were the nucleus of a wireless network that brought together creative technologists, digital artists and people with an interest in the free and democratic information. For instance, Indymedia London was formed out of activities at Backspace in 1999 (see also Medosch, 2016).

In 2002, a workshop that brought together people from Consume, London, with Berlin-based technology activists, led to the initiative Freifunk (free radio). Freifunk adapted the Consume idea to German reality and quickly became much bigger and more successful in terms of numbers than Consume had ever been. One reason for that was that there were areas in East Berlin and East Germany, which could not get ADSL connections for broadband because of the existence of proprietary fibre optics technology. Another reason why Freifunk could thrive was that it could recruit many highly skilled activists. Those two factors allowed Freifunk to spread rapidly, so that within a few years Berlin alone had more than 1300 free radio nodes and many more users. However, after a phase of rapid growth in the early 2000s, this development slowed down in the second half of the 2000s, some networks even started to shrink. More recently, in a world after Snowden's revelations (Harding, 2014), Freifunk started to thrive again.

At around 2003, Guifi.net started in the rural area of Catalonia, near the small town of Vic. At the time, it was impossible to get broadband internet in the villages. An initiative began to build wireless community networks. Guifi.net developed around ideas similar to those of AWMN, Consume and Freifunk, but with a number of differences. It set itself the explicit goal to bring good internet service to the highest number of people at the cheapest price, and it developed a system where people could pay technicians to install a network node. Guifi.net did not see this as in contradiction with the idea of the network commons. As long as those nodes set up by small service providers joined the network commons, the fact that some money was paid for installation was not in contradiction to that. Guifi.net explicitly defined itself as a network commons, but using the term common-pool resource. This way of working enabled Guifi.net to become one of the fastest growing networks standing at 30,500 nodes and many more users at the time of writing.

The projects just described constitute the counter-thesis to the network model offered by the ISP and telecom corporations with their centrally managed operations and their practices of metering and controlling the data flow in their networks for financial purposes. Those projects attracted and were based on the voluntary labour of ethical technology activists, also known as hackers. Many of the participants had already had an interest in free and open source software and in particular in the cooperative idea on which it was based, commons-based peer production. Community networks attracted them because it allowed them to extend free software ideas to the network. Since the early 2000s, the network commons has become like a self-regulating dispositif. The dispositif consists of an assemblage of material infrastructures, shared practices and ideas to which a community of practitioners voluntarily subscribes. Central to this dispositif is 
the decentralised utopia - decentrality as a political idea mapped onto a technological structure. The network commons activists share strong beliefs against centralised political control and are convinced that only a decentralised network is a strong and resilient network. Those ideas flow together in initiatives building firmware with mesh routing protocols. A firmware is a software that runs on a specific piece of hardware. Community networks often write their own firmware, based on free and open source software, to replace the proprietary firmware of manufacturers. Routing protocols are technical conventions embedded in software that manage the actual data flow in networks. In the early years of the network commons routing protocols were an issue because existing protocols were built for cable-bound networks with fixed routes, as opposed to the more fluid electromagnetic environment where conditions constantly change and nodes can drop off and new nodes come online. At around 2004, ethical technology activists from Freifunk in Berlin and Funkfeuer in Austria started to experiment with the mesh network routing protocol OLSR. Later, a group around Corinna 'Elektra' Aichele developed a different mesh network routing protocol under the name of BATMAN. Recent variants of those protocols are now working inside the firmware used by Freifunk, Guif.net, Funkfeuer and other networks. Firmware with mesh network routing protocols do not need manual configuration, but automatically recognise when new nodes join the networks or existing ones drop out. Their capacity to automate route-finding allows the ad-hoc autoconfiguration of fixed and mobile wireless ad-hoc mesh networks. As Elektra, one key developer in Berlin put it, "the sleeping beauty of mesh network protocols has been kissed awake by the community networks" (Aichele, 2007, p.15).

The technology activists of the network commons have made a strong contribution to techno-social innovation with mesh-routing protocols and firmware based on it. Their achievements, however, are not merely technological. The rise of the network commons in general and the development of mesh network protocols by the community, in particular, illustrate that technologies are inherently social. We have been made to believe that the development of technology is somehow autonomous, that technology follows a course of its own and that people have to adapt to the technologies that are created by corporate research labs and universities. Yet the development of the network commons in Athens, Catalonia and Berlin followed trajectories of the social development of the communities it was connected with. In such a reading, the technology is not a thing, an object, but the result of social exchanges and cooperative practices between communities of practitioners. Those communities do not only consist of ethical hackers who carry out the difficult technical tasks of writing code, but also their wider social environment. The way those networks are developed implies that knowledge transfer between developers and users takes place. Consume, London, and Freifunk, Germany, strongly emphasised workshops and local knowledge as a way of building the network commons. In the process, the technology became socialised, decommodified and demystified.

The network commons performs a de-commodification of network communications. Internet service providers and telephone companies sell communication as a commodity. The network commons cannot be turned into a commodity, it provides use-value without exchange value (even if some mechanisms for cost-sharing are involved). The liberation of network communications from the commodity form reverses a long-term secular trend. The rise of the capitalist political economy was based on the enclosure of the commons. Now, the network commons offers an outlook on a post-capitalist political economy. This is significant because most other commons movements come from the margins of society where, for instance, subsistence farmers fight for keeping forests as a commons. The 
network commons, on the other side, emerges from the most developed point of informational capitalism.

Technology is surrounded by an aura of being complex and difficult to understand. This adds to the general notion of commodity fetishism, the mystified belief that technologies are merely things, dead objects. The network commons illustrates that technologies are embodied social relations. The way those projects work makes it clear that technologies are not just things but techno-social systems (Bijker et al., 1987). When building firmwares and mesh network technologies the developers in Berlin, Vienna and Catalonia answered the needs of the network commons. As those projects developed, they also developed strong self-governance mechanisms. Initially, projects such as Consume, London, or Freifunk Berlin, were motivated by quite strong anarchist sets of beliefs - not anarchism with capital A, but a shared set of values that opted against any centralised political regulation of the networks and against centralised technical structures. As those projects grew, they experienced many social problems, internally and externally, such as bad legislation or attempts by individuals and groups to enclose the network commons. As a response, Freifunk and Guifi.net, in particular, have developed comprehensive mechanisms for conflict resolution and self-governance. From such a point of view, the term community network is outdated because those initiatives have become something much larger and more complex than simply communities.

For all those reasons together, the network commons can be seen as a kind of model for a transversal $r$ /evolution. In the midst of informational capitalism come recipes that point beyond it. However, I do not want to glorify the technology. The network commons should not turn out like another version of internet utopianism of the 1990s. In the $1990 \mathrm{~s}$, the internet was hailed as a new electronic agora. The idea was circulated that direct, participatory democracy as practised in ancient Athens could be re-created, albeit on a much bigger scale, through the Net. The Greco-French philosopher Cornelius Castoriadis (Castoriadis, 1997) has provided a vivid and insightful description of Athenian democracy. Castoriadis emphasised that voting was one of the least important aspects of Athenian democracy. What mattered more was that large numbers of people participated in political life and negotiated subjects in intense exchanges, forming large ad-hoc committees on specific subjects, often voting by acclamations - expressing a majority decision reached by other means than that of voting. Speeches tended to be short and sharp, and the outcome of decisions was determined by educated, lucid and rational judgement achieved at collectively. The democratic society for Castoriadis was the selfinstituting society. It was, in a Hegelian sense, a society that became conscious of itself as a political unity which produced its own institutions, but was also capable of changing those institutions when needed. Politicians, while democratically elected, could also be removed from positions relatively quickly. The self-instituting society, Castoriadis stressed, had the means of educating itself to create a collective social imaginary. However, only about 5000 free male citizens participated in the political agora in Athens. Internet utopians in the 1990s argued that egalitarian internet communication could provide the conditions for much larger numbers of people to participate in democratic processes. The electronic agora of the 1990s, however, was based on a disembodied notion of information. Advocates of internet utopia such as John Perry Barlow posited the digital communications sphere as a reality separate from that of government and big industry, those "weary giants of flesh and steel" (Barlow, 2016). In the time that has passed since those weary giants have also grown electronic nerve networks. The internet has come under corporate and government control. 
The network commons is an embodied, concrete utopia. However, left to itself, the network commons can suffer enclosure or suffocation in an increasingly difficult economic and political environment. Those ideas about self-regulation and decentrality, although initially coming from the left, are not in contradiction to the mode of production of advanced informational capital. People in the capitalist core countries are freed up to devote their time to innovation practices and to participate in the peer-based-commons production. Yet the achievements of the network utopia are based on the dark secrets of informational capitalism, such as the displacement of labour and ecologically unsustainable practices. While informationalist ideology stresses individualism and entrepreneurship, capitalism's advance is guaranteed by the development of the general intellect, the sum total of abstract social labour. While the people who are building the network commons often share beliefs in leftist ideas, their activity, on the forefront of immaterial labour, contributes involuntarily to those mechanisms which, on a global scale, increase inequality. Unfortunately, the peer-to-peer based methodology of ethical hackers offers no way of resisting appropriation of their code. Once more capitalism shows its capacity to appropriate concepts and technologies developed outside it. For all those reasons together, the network commons must not stay isolated but develop lively links with other commoners.

\section{Conclusions: outlines of a project}

As the icy wind of informational capitalism blows down the roads of the projective city, conditions are as bad as they could be for any project that carries utopia in its DNA. The network commons is embedded in the current political economy and exposed to its force fields. Returning to Tafuri's analysis, what we can learn from him is that at any particular time in history there is only one option. The overall dynamics of informational capitalism points to more information, more automation, more bandwidth, more surveillance. Yet just like the avant-gardes of the 1920s, the ethical technology activists who build the network commons imbue this general and not reversible historical tendency with a whiff of utopia, by providing hints, models, examples of how another type of development is possible. This 'other' development cannot be an alternative in the same way that the green movements in the 1970s and 1980s proposed an alternative to industrial capitalism; it cannot be a return to subsistence farming and small-scale industry as some leftwing romantics in the commons and maker scenes appear to hope for; but a way forward that combines relentless innovation on the technological side with social innovation using the internal dynamics of the system to drive it into a different direction.

Like in the 1920s, different types of avant-garde movements join forces in this effort. In recent years, a number of digital artists and media artists such as Shu Lea Cheang and Annemarie Maes have shown ways in which techno-social innovation and contemporary art can be combined. In Steam the green, Stream the field (2001-2002) in New York, Cheang highlighted the potential of the coming together of the network commons with social self-organisation and organic farming. Together with the collective Take2030 and the Hivenetwork crew around artist-engineer Alexei Blinov, Cheang realised a string of projects based on an 'after the crash' scenario: capitalism has hit its final big crisis and the commercial networks are down; the only network still going is the network commons. More recently, Cheang has been linking different data sets of nature and culture with Composting the city, Composting the Net (2012-2013), and with Seeds Underground 
Exchange (2013-2014). The work of Brussels based artist Annemarie Maes brings together wireless networking, open source technology, machine learning algorithms with urban beekeeping and ecological concerns. The artists demonstrate the need to bring together different forms of commoning. However, unlike in the 1920s, the real avantgarde today is the technology activists and ethical hackers. They were the first to have adopted the new ways of working - commons-based peer production - while many artists appear to be stuck with individualistic notions of genus and success in the projective city. The agency of the avant-garde of techno-social activists produces use-values rather than exchange value. The network commons created by them could become a transversal infrastructure that joins together other commons and commoners in the networked city.

The network commons has shown that an alternative approach is possible not only in small and local initiatives such as urban gardening, but also at the most advanced poles of development. It could become a model for alternative energy projects where energy is produced locally and for large networks of food provision. The network commons has already shown that a commons mode of production can outperform state and market players. Peer-to-peer forms of cooperation need not be considered marginalised but could become the main way of infrastructural, political and cultural cooperation, rather than relying on outdated centrally organised forms of production and consumption. The notion of innovation needs to change so that it comprises not only new products but also new social forms of self-organisation beyond the market and the state. There are signs that there is a great desire for such political social innovation. For instance in Spain, in Barcelona and Madrid, it was movements rather than parties, that have won the mayoral seats in elections in 2015. The network commons could become a transversal infrastructural layer, reaching across society and different domains, becoming a revolutionary enabler of a new urban life in a way that points beyond capitalism as we knew it.

Yet unlike the time when Tafuri worked on project and utopia, we are now standing in the ruins of the society of the plan. The planned society has become a corpse which has been decomposing for 40 years. This implies that any return to a unified one-utopiafor-all would be either impossible or based on a new authoritarianism. The notion of utopia itself needs to be decentralised, and de-linked from any ideology of progress. This time, the situation is much more fragmented and inconsistent. We are already living 'after the crash' where the rich retreat into safe heavens while the world around disintegrates. Thus, the revival of the city as utopia and project would also have to be based on a strategic universalism (Gilroy, 2001) that reconfigures an emancipatory project for the multitudes.

\section{References}

Aichele, C. (2007) Mesh: drahtlose Ad-hoc-Netze, Open Source Press, München.

Bacon, F. (2014) New Atlantis.

Banham, R. (1962) Theory and Design in the First Machine Age, Architectural Press, London.

Barlow, J.P. (2016) 'A declaration of the independence of cyberspace', Electronic Frontier Foundation, 20 January, https://www.eff.org/cyberspace-independence

Batchelor, R. (1994) Henry Ford, Mass Production, Modernism, and Design, Manchester University Press ND, Manchester, New York. 
Benkler, Y. (2006) The Wealth of Networks: How Social Production Transforms Markets and Freedom, Yale University Press, New Haven [Conn.].

Berry, D.M. and Moss, G. (2009) On the 'Creative Commons': A Critique of the Commons without Commonalty, Vol. 2005, No. 2, September, http://www.freesoftwaremagazine.com/free issues/issue_05/commons_without_commonality/

Bijker, W.E., Hughes, T.P. and Pinch, T.J. (Eds.) (1987) The Social Construction of Technological Systems: New Directions in the Sociology and History of Technology, MIT Press, Cambridge Mass.

Bloch, E. (1962) Subjekt-Objekt; Erläuterungen zu Hegel, Suhrkamp, Frankfurt am Main.

Bloch, E. (1988) The Utopian Function of Art and Literature: Selected Essays, Zipes, J. and Mecklenburg, F. (Trans.), MIT Press, Cambridge, Mass.

Boltanski, L. and Chiapello. E. (2005) The New Spirit of Capitalism, Verso, London.

Brenner, R. (2002) The Boom and the Bubble: The US in the World Economy, 1st ed., Verso, London.

Campanella, T. (2009) The City of the Sun: [a Dialogue between a Grandmaster of the Knights Hospitallers and a Genoese Sea Captain, His Guest].

Castells, M. (2010) The Rise of the Network Society, 2nd ed., The Information Age: Economy, Society and Culture, Vol. 1, Wiley-Blackwell, Oxford.

Castoriadis, C. (1997). The Castoriadis Reader, Cambridge, Oxford, Blackwell Publishers, Mass.

da Rimini, F. (2007) 'Social technologies and the digital commons', Handbook of Research on Open Source Software: Technological, Economic, and Social Perspectives, IGI Global, Hershey, Pennsylvania, pp.51-67.

Debord, G. (2004) 'Report on the construction of situations and on the terms of organization and action of the international situationist tendency (1957)', Guy Debord and the Situationist International: Texts and Documents, The MIT Press, Boston Mass., pp.29-50.

Dyer-Witheford, N. (1999) Cyber-Marx: Cycles and Circuits of Struggle in High Technology Capitalism, University of Illinois Press, Chicago.

Edwards, P.N. (1996) The Closed World: Computers and the Politics of Discourse in Cold War America, MIT Press, Cambridge, Mass.

Florida, R.L. (2002) The Rise of the Creative Class: And How It's Transforming Work, Leisure, Community and Everyday Life, Basic Books, New York, NY.

Froebel, F., Heinrichs, J. and Kreye, O. (1980) 'The new international division of labour: structural unemployment in industrialised countries and industrialisation in developing countries', in Burgess, P. (Trans.): Éditions de la Maison des sciences de l'homme, Cambridge University Press, Cambridge, Paris.

Gilroy, P. (2001) Against Race: Imagining Political Culture Beyond the Color Line, Belknap Press of Harvard University Press.

Guattari, F. (2011) The Machinic Unconscious: Essays in Schizoanalysis, Semiotext(e).

Harding, L. (2014) The Snowden Files: The Inside Story of the World's Most Wanted Man.

Hardt, M. and Negri, A. (2001) Empire, Harvard University Press, Cambridge, Mass.

Harvey, D. (1989) The Condition of Postmodernity: An Enquiry into the Origins of Cultural Change, Basil Blackwell, Oxford.

Helfrich, S., Bollier, D. and Heinrich-Böll-Stiftung (Eds.) (2015) Die Welt der Commons Muster gemeinsamen Handelns, Transcript, Bielefeld.

Holmes, B. (2004) 'The flexible personality: for a new cultural critique', Economising Culture: On 'the (digital) Culture Industry', Autonomedia, New York, pp.23-54.

Illich, I. (1973) Tools for Conviviality, Harper \& Row, New York.

Lefebvre, H. (2014) Critique of Everyday Life, Elliott, G. (Ed.), Moore, J. (Trans.), Verso, London.

Lemstra, W., Hayes, V. and Groenewegen, J. (2010) The Innovation Journey of Wi-Fi: The Road to Global Success, Cambridge University Press. 
Mandel, E. (1978) 'The permanent arms economy and late capitalism', Late Capitalism, Verso, London, pp.274-310.

Marcuse, H. (1968) 'The affirmative character of culture', in Shapiro, J.J. (Trans.): Negations: Essays in Critical Theory, Beacon Press, Boston, pp.88-133.

Marcuse, H. (1971) Reason and Revolution: Hegel and the Rise of Social Theory, Routledge and Kegan Paul, London.

Marx, K. (1972) The Economic and Philosophic Manuscripts of 1844, Norton, New York.

Marx, K. (1976) Capital Volume I: A Critique of Political Economy, Fowkes. B. (Trans.), Vol. 1, 3 Vols., Penguin Books, London.

Marx, K. (1993) Grundrisse: Foundations of the Critique of Political Economy, Rough Draft, Penguin Books, London, New York.

Medosch, A. (2016) 'Shockwaves in the new world order of information and communication', A Companion to Digital Art, Blackwell Companions to Art History, John Wiley \& Sons, pp.355-383.

Negri, A. (1988) 'Crisis of the planner state: communism and revolutionary organisation', Revolution Retrieved: Writings on Marx, Keynes, Capitalist Crisis and New Social Subjects, Left Bank Books, London, pp.91-148.

Perez, C. (2009) Technological Revolutions and Techno-Economic Paradigms, Working Papers in Technology GOvernance and Economic Dynamics, No. 20, http://technologygovernance.eu/ files/main/2009070708552121.pdf

Sassen, S. (2001) The Global City: New York, London, Tokyo, Princeton University Press.

Simmel, G. (2000) 'The metropolis and mental life', The City Cultures Reader, Routledge Urban Reader 3, Routledge, London and New York, pp.12-19.

Tafuri, M. (1973) Progetto e utopia. Architettura e sviluppo capitalistic, Laterza, Roma-Bari.

Tafuri, M. (1976) Architecture and Utopia: Design and Capitalist Development, MIT Press.

van Doesburg, T., El Lissitzky and Richter, H. (1922) 'Declaration of the international fraction of constructivists of the first international congress of progressive artists', Art in Theory, 19002000: An Anthology of Changing Ideas, pp.314-316.

Vaneigem, R. (1983) The Revolution of Everyday Life, Translated by Donald Nicholson-Smith, Seattle, Welcombe, Left Bank Books, Rebel Press, England.

Young, M. and Willmott. P. (1986) Family and Kinship in East London, 2nd ed., Routledge and Kegan Paul, London and Boston.

\section{Note}

${ }^{1}$ Capital is always mystifying due to the working of commodity fetishism. But under the specific conditions of informational capital new mystifications have arisen. 